\title{
Sociology of Bugis Society: An Introduction
}

\author{
Mr. Ahmadin \\ Faculty of Social Sciences, Universitas Negeri Makassar, Indonesia \\ E-mail: ahmadin@unm.ac.id
}

\begin{abstract}
This paper describes the socio-cultural heritage of the Bugis people in South Sulawesi from the perspective of sociology. The study approach in this research is historical sociology, which is intended to explore the socio-cultural values of the past as a legacy that needs to be preserved. The life of the Bugis people throughout its history is very interesting to study, at least as a comparison with the reality of life now, namely after one of the ethnic groups in Sulawesi Province was influenced by modernization. This sociological study of Bugis society begins with a brief description of Bugis people and the world, social interactions, kinship systems, social stratification, social mobility, and social changes in Bugis society. Contact with the outside world and the Bugis people's penchant for wandering, caused this ethnic group to develop rapidly and even history records that the Bugis people built a center of government and became rulers of the kingdom in the archipelago.
\end{abstract}

Keyword: Bugis society, sosiologi, socio-cultural heritage

\section{INTRODUCTION}

In general, Sociology is understood as a branch of social science that studies society and its influence on the development of human life. Thus, Sociology is called "the study of society" which contains knowledge about the nature of society, community behavior, and community development. The original nature of the dynamic community along with the demands of the needs and changing times, caused this discipline to later be transformed into various themes and study approaches. An interesting question was asked, namely how did Sociology actually begin?

It is very difficult to answer this question, as acknowledged by sociologist James M. Henslin, because according to him, the process of understanding social life has been initiated and carried out by humans since ancient times. Professor Emeritus of the University of Southern Illinois College of Sociology, Erwardsville, revealed that early humans had asked why there was war, why some people were more powerful than others, and why certain people were rich (by the time, pen), while others were poor. The answer to this question is based on superstition, myth, or even the position of the stars without any process of testing their assumptions. In its development, this community study has become science by using theory as a tool to test the truth through a series of study/research processes. Around the mid-1800s, sociology came up with a scientific method in testing the truth of ideas (Henslin, 2007).

The earliest originator and proponent of this type of sociology was Auguste Comte 
(1798-1857), who was later popularly known as the Father of Sociology. From the monumental work of French scientists entitled "Cours De Philosophie Positive" or positivism (positivism), people refer to the etymological notion of Sociology, namely socius (Latin word) which means friends or with other people and logos (Greek word) which means story., talk, or study about (Henslin, 2007). Sociology which means "talking about society", is different from geology (geo means earth) which talks about the earth, biology (bios means life) talks about life, and anthropology (anthropus means human) talks about humans. For Auguste Comte, sociology is a general social science which is the last result of the development of science. Sociology builds on the advances made by other disciplines (Soekanto, 2002).

James N. Henslin, a sociologist from Southern Illinois University, Edwardville, explains that sociology offers perspective, which is a view of the world. Sociological perspective (or imagination about the world), according to him, can open a window into the unknown world and offer a fresh view into the known world. In this context, Henslin exemplifies a text that you will find yourself in the midst of the Nazis in Germany, the South American fighters, and even the people he has visited at the landfills in Cambodia. On the other hand, according to him, you can also find yourself looking at your own world. Well, when we look at the other world or the world itself, according to him, the sociological perspective allows us to gain a new view of social life (Henslin, 2007).

Learning from many experiences as an effort to self-reflect, that is what inspired him to formulate a sociological perspective. According to him, the sociological perspective is to examine how the context affects human life. Thus, Henslin recommends that to find out why humans do what they do, sociologists study social location. Mentioned, among others, such as: occupation, income, education, gender, age, and race-ethnicity affect human ideas and thoughts.
Referring to Henslin's view of perspective or imagination about the world in an effort to find a new perspective on social life, this paper examines the world and the Bugis people, one of the ethnic groups in South Sulawesi Province. As one of the largest ethnic groups in the province, the Bugis people have a distinctive socio-cultural heritage that is interesting to examine from a sociological perspective. Some of the main things studied in this research include: Bugis world and society, social interaction, kinship system, social stratification, social mobility, and social change.

\section{RESEARCH METHOD}

Similar to other social sciences, the object of sociology is society which is seen from the point of view of human relations and the processes that arise from human relations in society (R. R. Ahmadin, 2021). There are several methods in sociology that are used in the process of investigation or research, as follows:

a. Historical-method, which is a way of tracing the culture and structure of the past society to be used as a guide in the future based on the principles contained in it.

b. Comparative-method, namely comparing a society with another society, a group with another group, a culture with another culture, then we will get lines of equations that are generally accepted, so that we can give predictions on the next development.

c. Statictical-method, which is measuring social phenomena that appear quantitatively, which then we look for the main thing which will also be qualitative.

d. Case-study method, which investigates events that occur around community groups, as well as certain institutions to get the main outlines of those events. This method is also known as a survey (Abdulsyani, 2002).

In addition to the four methods mentioned above, sociology researchers also 
often use sociometric techniques in order to analyze various social phenomena mathematically. In this method using scales and numbers in examining the close relationship between individuals and society. There are at least three forms of sociometric analysis, as described below:

a. Sociometric matrix, which is the analysis of data related to the closeness of relationships by using regular rows of numbers or symbols that express various individual choices towards other individuals as members of the group.

b. Sociogram, which is a diagram of the choices of each individual towards other individuals.

c. Sociometric index, namely single numbers that indicate the characteristics of individuals (who live) (Abdulsyani, 2002).

Another sociological method is related to the way or logic of thinking, namely inductive thinking and deductive thinking. The method of inductive thinking is a way of concluding a specific situation or phenomenon to obtain generally accepted principles. On the other hand, the deductive method is based on general circumstances to get specific conclusions. If the approximation of the method is based on the type of data, then the empirical and rationalistic methods are also known. The empirical method focuses on real phenomena in society, while the rationalistic method emphasizes logical thinking about an event in society (Abdulsyani, 2002).

The empirical method in modern sociology is realized by research or research, namely a way of studying a problem systematically and intensively to gain more knowledge about the problem. Research in this case can be basic or applied. Meanwhile, the rationalistic method was widely used in the past (and even still exists today, such as functionalism) by scholars in Europe (Soekanto, 2014). The stages of social research in the realm of Sociology studies, as in general research activities, are starting from topic selection and problem determination. The problem is defined as the gap between expectations (das solen) and reality (das sein) (A. Ahmadin, 2013).

\section{RESULT AND DISCUSSION}

Scientific studies on the Bugis and their cultural heritage have been carried out by many researchers in various approaches. A well-known priest from the Netherlands B.F. Mathes, who once served in Makassar, has started conducting research on the Bugis since 1884. The results of collecting data on the Bugis people and their cultural heritage, including Lontara' were published in a book entitled "Makassarsche en Boegineesche Woordenbook". Likewise, R.A. Kern has studied Bugis society and has succeeded in compiling the monumental work "La Galigo" which is a literary work commensurate with the epic Maha Barata (A. Ahmadin, 2015). In fact, there are many works on other Bugis tribes, including Christian Pelras' writings about Bugis Man (Pelras, Abu, \& Arsuka, 2006).

In particular, the study of political organizations from the 14th to the 16th centuries has received special attention from Caldwell, who wrote about typical preIslamic powers and rulers (Caldwell, 1995). Similarly, Errington writes about the politics of the formation and maintenance of sociopolitical spaces in the former Dutch East Indies, especially in Luwu, South Sulawesi (Errington, 2014)

This paper describes a small part of the big name of the Bugis Ethnic, namely the socio-cultural heritage that has been studied in a Sociological study approach. The purpose of this writing is a form of refreshing memory about humans and the Bugis world that can be used as learning material for the current Bugis generation. At the very least, it becomes a material for comparison between the modern reality of Bugis society and the past based on local wisdom (M. Ahmadin, 2019).

\section{Bugis Word and Society}

The Bugis community researcher, Cristian Pelras notes that the Bugis are one of 
the various ethnic groups in Southeast Asia, with a population of more than 4 million people. The Bugis people inhabit the southwest part of the island of Sulawesi and belong to the large Austronesian family. As a result of their internal evolution and interactions with various outside civilizations, namely China, India, Islam, and Europe, in turn, the Austronesian population spread over the seas of Southeast Asia since before Christ developed into various ethnic groups. Show a variety of different traditions and cultures, among which the famous ones are Malay, Javanese, and Balinese (Pelras et al., 2006).

Susan Bolyard Millar, the author of the Bugis book "Weddings: Ritual of Social Location in Modern Indonesia", explains that the area of origin of the Bugis is located in the southwestern hemisphere of the peninsula of the island of Sulawesi (Celebes). The island is the fourth largest in Indonesia and consists of an impassable mountainous central mainland, from which stretch the four main peninsulas of Sulawesi. Cultural relations between the Bugis and other ethnic groups inhabiting the other peninsulas of the island are of little importance. But cultural, political, and kinship ties extend far into the past that bind the Bugis with another group that inhabits this peninsula known as South Sulawesi (Millar, 1981).

The land area of South Sulawesi stretches over 65,000 square kilometers [Java for comparison, has an area of approximately 132,000 square kilometers] (Pelras et al., 2006). Based on population data in 1976 by the Sulawesi Regional Development Survey (SPRS), the mainland of South Sulawesi is covered with fertile volcanic soil that supports the life of approximately $5,500,000$ people. This province is one of the largest population owners outside Java. The population density of approximately 200 people/ $\mathrm{km} 2$ in some areas is high for outside Java, only surpassed by North Sumatra (Millar, 1981).

In history, the Bugis people are recorded as a migratory people and they are very well known throughout the Indonesian
Archipelago and the Malay Peninsula. Lineton notes that they came as traders, robbers, and settlers. At the beginning of the 20th century there were large settlements of Bugis people on the east coast of Peninsular Malaysia (Lineton, 1975), on the east and south-southwest coasts of the island of Borneo, and various places around it. It is also described that in this century there has been a large migration to Sumatra, Sumbawa, Ambon, Java, Singapore, Malaysia and the eastern part of Kalimantan who live on the coast (Millar, 1981); (Millar, 1983).

The South Sulawesi peninsula is inhabited by several ethnic groups. Makaliwe when classifying the people of South Sulawesi, wrote that the Toraja and Duri are a separate large ethnic group, descended from the region's earliest settlers. As for the Bugis, Makassarese, Mandar, and Selayar people, each constitutes another ethnic group, descended from later settlers (Makaliwe, 1969). In addition, Mills also makes a grouping by referring to linguistic evidence that supports the theory that the Makassarese, Bugis, Mandar, Duri, and Toraja people are now part of the deuteroIndonesian migration generation (Mills, 1975).

Meanwhile, Pelras only divided the population of South Sulawesi into four ethnic groups according to the cultural differences they encountered, namely Bugis, Makassar, Mandar, and Toraja (Millar, 1981). Bugis world exists and is spread in various places, not only in Indonesia but in several other countries such as: Malaysia, Singapore, Pasir, and others.

One special cultural characteristic possessed by the Bugis and Makassar people, especially in the 17th century, was Siri' and Pesse (Bugis) or Pacce (Makassar). Siri' is a concept that includes ideas about self-worth and shame. In its implementation, these two socio-cultural values are not contradictory because shame implicitly contains the concept of self-esteem (Andaya, 1981). This conception of the value of Siri' and Pesse is what incarnates the outlook on life and 
motivation in various life activities of the Bugis people.

\section{Social Interactions}

Social interaction is a general form of social process (which can also be called a social process), which is the main condition for the occurrence of social activities. Social interaction can take place between individuals or between groups in a society. A person who meets the street or at the market and then shakes hands and talks, then this activity is an example of interaction. Even someone who is standing or hanging on the side of the road and sees other people passing by and does not have time to reprimand each other, this is also classified as social interaction. Why? Because speaking or not, there will be something or the impression that arises when someone looks at other people, whether that impression is pleasant or not. The response that arises from the impression then encourages or triggers a reaction, then that's when social interaction occurs.

Social interaction will only take place or occur if it meets two requirements, namely there is social contact and there is social communication. Social contact is a relationship between one or more people through conversation with certain aims and objectives. Social contact can occur directly such as face to face or indirectly, for example through the mediation of technological devices, such as: telephone, letter, short message via social media, and so on.

The two types of interaction by Soekanto, are named primary and secondary social contacts. The first type of contact such as: face to face, meeting, handshake, conversing, between parties who make social contact, Meanwhile, the second type of contact occurs through intermediaries, such as: telephone, mail, radio, and so on (Soekanto, 2014).

The Bugis people in carrying out social interactions always uphold the noble values that are the legacy of their predecessors. Guidelines for social life as the basis for patterning various types of social interaction, sourced from Lontara' in the form of moral messages (paseng) and oral sources in the form of expressions (pau-pau).

The life of the Bugis people has always been an integral part that cannot be separated from pangaderrang, a philosophy of life that has 4 (four) principles, as follows: (1) Mappasilasae principle, which manifests ade' for harmony in life in attitude and behavior; (2) Mappasisaue principle, namely the manifestation of ade' in inflicting lashes on the violator of customary provisions; (3) the principle of Mappasenrupae, namely the manifestation of ade' for the continuity of previous patterns; and (4) the Mappalaiseng principle, namely the manifestation of ade' in choosing the boundaries of human relations with social institutions, in order to avoid problems (A. Ahmadin, 2015).

These social values or norms are used by the Bugis community as a guide in interacting for various interests. The point is that the four principles above create patterns of attitude and action, the rule of law, the consistency of the principles of life, and the mechanism of social order.

\section{Kinship Systems}

The kinship system developed from a single family group. Bugis people recognize the existence of a nuclear family called "sianang" (maranak). Sianang (maranak) consists of father, mother, and children who live in the same house. However, it is not certain that in one household there are also several other family members such as brother/sister-in-law, brother, nephew, inlaws, grandmother/grandfather. In connection with that, the Bugis society also recognizes the extended family (Andi Ima Kesuma, 2012); (Kesuma, 2004).

In addition to the nuclear family and extended family, people in Bugis also recognize a group of relatives called blood relations, both from the father's side and the mother's side. For the local community, the family as mentioned above is called "seajing" or sompung lolo, meaning the connection of the stomach (intestine). Regarding seajing, 
the Bugis community also divides it into two elements, namely seajing macawe (close family) and distant family (seajing mabela). The Bugis ethnic community also considers their lineage based on parental or bilateral principles (lineage from both the father and the mother side) (Andi Ima Kesuma, 2012).

The ideal marriage for the Bugis people is cousins, especially second-degree relatives (sappokadua $=$ two cousins). The purpose of marriage between second degree cousins is to bring back relationships that are considered to have started to drift apart. The custom of settling after marriage tends to follow a bilokal pattern, meaning the freedom to choose a place to settle, both for the wife's relatives and for the husband's relatives. But what is more dominant is that the husband follows the wife who lives in the house of her parents' parents.

\section{Social Stratification}

The principle of hierarchy among the Bugis people is actually very simple. In the book La Galigo contains the mythology of the origin of their ancestors and confirms the existence of two types of humans, namely those with white blood (Madara takku) who are called descendants of the gods and red blooded humans (tau sama), namely ordinary humans, commoners, and slaves. This division of human types is absolute and cannot be confused (Pelras, 1997). Meanwhile, according to Fridericy, that the social stratification of the Bugis-Makassar community consists of 3 layers, namely Anak Karong, Tomaradeka, and Ata (Mattulada, 1975). If there is a marriage between the two groups, it can raise the lower class to be high, and vice versa reduce the degree of the high class. However, a man with a lower rank cannot marry a woman of a higher rank, on the other hand, a man with a higher degree can marry a woman of a lower rank (Najamuddin, Patahuddin, Bahri, \& Rasyid, 2009).

The highest level in the hierarchical structure of social stratification of the Bugis society after the King is ana' Mattola", the child who can replace his father's position as king in the future. After Ana Mattola, it is divided into two parts, namely Ana Seng'eng and Ana' Rajeng, which is then also divided into two levels. If there is a marriage between a man and a woman of different levels, then the position of the child is in the middle of the position of his parents, for example, if an Ana 'Mattola marries a woman from an ordinary circle, then the child born is called Ana' Cera Siseng'. Furthermore, if Ana Cera 'Siseng' marries an ordinary woman, then the child born is called Ana' Cera Tellu', if Ana' Cera Tellu' marries an ordinary person, then the child born is called Ampo Cinaga, Anang, Anakarung Maddara-dara. Below all of them are ordinary people (Tau Sama'a), and Tau Maradeka, and the lowest level is Ata' (Pelras, 1997).

In In another reference it is stated that the Bugis ethnic recognizes the existence of social layers according to the level of status in society, namely:

a. Arung (nobles): members of society who were classified as nobility during the royal era were people who had the highest degree in the level of social stratification. However, at the level of nobility can also be divided into two groups, namely the aristocratic group who had a position in the government at that time, slightly higher in rank than a nobleman who did not have a position in the government during the reign of the kingdom.

b. Tumaradeka (Most Community); Tumaradeka is a social layer of society that applies especially among people belonging to the Bugis ethnic group. Tumaradeka's status in the social structure was second only to the nobility. Community groups belonging to the Tumaradeka social status are people who do not have certain ties, except for the official rules that have been set by a king.

c. Ata' (slave); during the kingdom, ata' was the social layer at the lowest level according to the social stratification structure. Community members belonging to the ata' group, are people who are the messengers of the King. Moreover, community members 
belonging to ata' are also considered as belian or prisoners of war (Andi Ima Kesuma, 2012).

\section{Mobility and Social Change}

There is no society that does not change, that's a phrase that many people use to describe social change. Like people in other regions, the Bugis community in its development also experienced social changes or social transformations, among others, marked by the occurrence of vertical and horizontal social mobility. In many studies, it is stated that the Bugis community is very flexible with social mobility.

In its development, the social strata of the Bugis society were divided into 3, namely: (1) Nobles or Arung with the titles Andi, Petta, Etta, Puang, Opu, and Daeng; (2) To Maradeka (free people), and (3) Ata (slaves) (Hamid, 1985). An example of social mobility among the Bugis community is the appearance of new elites occupying public positions such as Topanrita (Toacca), namely ulama and scientists (religious and intellectuals); Tosugi, who are rich people because of their tenacity in trying so that they are successful and the manifestation of their success is realized by taking sides with the community; Towarani or Tobarani, those who have big souls so that they come forward to defend the interests of the people, both based on the laws of syara and ade' or Pangaderrang. Besides these three groups, there is another important group in the Bugis social group, namely Tosulesana, who have special skills such as strategists, technocrats, and other specialists whose ideas or creations are used for the benefit of society and the state. they are in the hearts of the people very close and needed by the kingdom or the state regardless of their blood descent (Mattulada, 1975).

In the social transformation of society, the position of ata in Bugis society until today is no longer firm. Except for the good background because of "losing the war or because of punishment for violations of adat and pangaderaang as well as pawning or selling so that the buyers make their status as slaves (Mattulada, 1975). Even though nowadays those who are classified as slave blood with backgrounds one of the ones described above, have made maximum efforts to reach one of the four elite classes, it does not automatically eliminate their original status instantly.

Mobility and social change then also create new types of social groups of various sizes. Bugis social groups can also be classified according to the size of their occupation in the economic field, including: (1) Padangkang group (wholesalers); (2) Pappalele group, namely the collector traders group that functions as intermediary traders who connect between producers and consumers or retail traders, and (3) The pabbaluk-baluk group, (retail traders), include: pappasa' (retail traders who constantly moving from one market to another or in the daily market); pagadde (kiosk merchant); pattoko, (shop trader) (Andi Ima Kesuma, 2012).

\section{CONCLUTION}

Sociology of the Bugis society is a description of the social life of one of the ethnic groups in South Sulawesi which is studied from the perspective of Sociology of History. The sociological study approach is intended to explain the "Bugis world" and the various realities of social life in it. Then the historical approach is intended to obtain a picture of the life of the Bugis community in the past and present which can be used as material to formulate a vision and strategy for developing the Bugis community in the future. Historically, Bugis society has an interesting socio-cultural heritage to be traced sociologically, such as patterns of social interaction originating from a philosophy of life called Pangaderrang, the basis for determining the level of social stratification according to the Book of La Galigo regarding two types of humans, namely white-blooded humans and whiteblooded humans. Red. Likewise, the kinship system whose formation is based on lineage and the process of expanding the scope of family relationships is an interesting object 
of sociological study. Even the sources and foundations of the formation of power and authority associated with the To manurung mythology are unique. However, the sociocultural dynamics that moved slowly but surely then created a series of social changes and the occurrence of social mobility among the Bugis people.

\section{REFERENCES}

Abdulsyani (2002). Sosiologi: Sitematika, Teori, dan Terapan. Jakarta: Bumi Aksara.

Ahmadin, A. (2013). Metode Penelitian Sosial. Makassar: Rayhan Intermedia.

Ahmadin, A. (2015). Kapitalisme Bugis: Etika Bisnis Berbasis Kearifan Lokal. Makassar: Rayhan Intermedia.

Ahmadin, M. (2019). The Social System of Buginese People in Modern Era: A Review of Sociological History. 1st International Conference on Advanced Multidisciplinary Research (ICAMR 2018). Atlantis Press.

Ahmadin, R. R. (2021). SOCIAL PROTEST OF WOMEN FARMERS REGARDING AGRARIAN CONFLICT. Journal of Legal, Ethical and Regulatory Issues, 24(4), 1-7.

Andaya, L. Y. (1981). The Heritage of Arung Palakka. Brill.

Andi Ima Kesuma, A. I. K. (2012). MORAL EKONOMI (MANUSIA) BUGIS. Rayhan Intermedia.

Caldwell, I. (1995). Power, state and society among the pre-Islamic Bugis. Bijdragen tot de Taal-, Land-en Volkenkunde, (3de Afl), 394-421.

Errington, S. (2014). Meaning and power in a Southeast Asian realm. Princeton University Press.

Hamid, A. (1985). Manusia Bugis Makassar. Jakarta: Inti Dayu.

Henslin, J. M. (2007). Essential of Sociology: A Down-to-Earth Approach (Sosiologi dengan Pendekatan Membumi). Jakarta: Penerbit Erlangga.

Kesuma, I. (2004). Migrasi dan orang Bugis: penelusuran kehadiran Opu Daeng Rilakka pada abad XVIII di Johor. Ombak.

Lineton, J. (1975). Pasompe'Ugi': Bugis migrants and wanderers. Archipel, 10(1), 173-201.

Makaliwe, W. H. (1969). An economic survey of South Sulawesi. Bulletin of Indonesian Economic Studies, 5(2), 17-36.

Mattulada, D. (1975). Kebudayaan BugisMakassar. Manusia dan kebudayaan Indonesia. Jambatan Jakarta.

Millar, S. B. (1981). Bugis Society: Given by the wedding guest. Cornell University.

Millar, S. B. (1983). On interpreting gender in Bugis society. American Ethnologist, 10(3), 477-493.

Mills, R. F. (1975). The Reconstruction of ProtoSouth-Sulawesi. Archipel, 10(1), 205-224.

Najamuddin, N., Patahuddin, P., Bahri, A., \& Rasyid, M. R. (2009). Sulawesi Selatan Tempo Doeloe (Muzaik Sejarah Lokal). Raihan Intermedia.

Pelras, C. (1997). The Bugis. John Wiley \& Sons.

Pelras, C., Abu, A. R., \& Arsuka, N. A. (2006). Manusia Bugis. Nalar: Forum JakartaParis: École Française d'Extrême-Orient (EFEO).

Soekanto, S. (2002). Mengenal Tujuh Tokoh Sosiologi.

Soekanto, S. (2014). Sosiologi suatu pengantar. 